\section{International Scientific Journal Theoretical \& Applied Science}

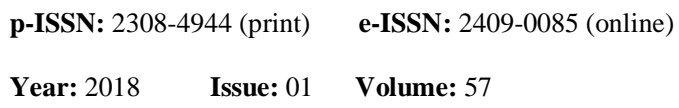

SECTION 12. Geology. Anthropology. Archaeology
E.E. Baloglanov

$\mathrm{PhD}$ student,

Scientific Researcher of Department of "Mud Volcanism" at the Institute of Geology and Geophysics, Azerbaijan National Academy of Sciences, Baku, Azerbaijan elnur1001@mail.ru

O.R. Abbasov

$\mathrm{PhD}$ in Earth Sciences, Associate Prof. Leading Scientific Researcher of Department of "Mud Volcanism" at the Institute of Geology and Geophysics, Azerbaijan National Academy of Sciences, Baku, Azerbaijan

R.V. Akhundov

Scientific Researcher of Department of "Mud Volcanism" at the Institute of Geology and Geophysics, Azerbaijan National Academy of Sciences, Baku, Azerbaijan

E.H. Hasanov $\mathrm{PhD}$ in Earth Sciences, Chief Geologist at the Department of Geophysics and Geology, Integrated Engineering Exploration Production Branch, SOCAR, Baku, Azerbaijan

K.A. Abbasov PhD in Physics, Associate Prof. at the Azerbaijan State Pedagogical University, Baku, Azerbaijan

I.M. Nuruyev Scientific Researcher at the Institute of Radiation Problems, Azerbaijan National Academy of Sciences,

Baku, Azerbaijan

\title{
ANOMALIES IN GAS-HYDROGEOCHEMICAL INDICATORS OF MUD VOLCANOES IN CONNECTION WITH SEISMIC ACTIVITY: ON THE BASIS OF MUD VOLCANOES DATA IN SHAMAKHI-GOBUSTAN (AZERBAIJAN) AND SAKHALIN ISLAND (RUSSIA)
}

\footnotetext{
Abstract: The paper is devoted to the results of studies on mud volcanoes of the Shamakhi-Gobustan region (Azerbaijan) and Sakhalin Island (Russia) in the aspect of intensifying their activities related to seismicity in adjacent areas. Monitorings in Azerbaijan and Sakhalin Island were carried out at different periods and were based on measuring temperatures and flow rates of active mud volcanoes. In addition, some distribution regularities of gas-hydrogeochemical indicators were established in connection with seismicity, based on monitoring of the chemical composition of gas and water ejected during the daily activity of the mud volcanoes. Depending on the magnitude of the seismic event in the periods before and after seismic activity some anomalous changes were recorded in the composition of fluids (for gases: $\mathrm{CO}_{2}, \mathrm{CH}_{4}, \mathrm{~N}_{2}, \mathrm{He}$ and for waters: $\mathrm{B}, \mathrm{SO}, \mathrm{Cl}$ ) carried to the Earth's surface by mud volcanoes for both study objects. Earthquakes with a large magnitude affect the temperature regime in the microforms of mud volcanoes too. During the activation of mud volcano, the channel ejects fluids from ultra-depth opens wider, which leads to an increase in the flow of gases from deep sources, in which the predominant components are $\mathrm{CO}_{2}$ (in Shamakhi-Gobustan) and $\mathrm{CH}_{4}$ (on Sakhalin Island).
} 
Key words: mud volcanism, fluids, monitoring, seismicity, Shamakhi-Gobustan, Sakhalin Island, gryphon activity.

Language: English

Citation: Baloglanov EE, Abbasov OR, Akhundov RV, Hasanov EH, Abbasov KA, Nuruyev IM (2018) ANOMALIES IN GAS-HYDROGEOCHEMICAL INDICATORS OF MUD VOLCANOES IN CONNECTION WITH SEISMIC ACTIVITY: ON THE BASIS OF MUD VOLCANOES DATA IN SHAMAKHI-GOBUSTAN (AZERBAIJAN) AND SAKHALIN ISLAND (RUSSIA). ISJ Theoretical \& Applied Science, 01 (57): 176-185.

Soi: http://s-o-i.org/1.1/TAS-01-57-32 Doi: crossef https://dx.doi.org/10.15863/TAS.2018.01.57.32

\section{Introduction and Background}

Mud volcanoes give necessary information about the depths of the Earth, as well as complex geological and geochemical processes occurring on inaccessible depths for exploratory wells. $[1 ; 7 ; 8$; $11 ; 31 ; 32]$. In recent years, various aspects of mud volcanism: the conditions for the formation of mud volcanoes, the tectonic features of mud volcanic areas, the geochemistry of rocks and fluids, the connection with the hydrocarbon systems of large depths and etc. have been studying in detail [30]. Regions of a complex tectonic structure are distinguished by active seismogeodynamic properties. The strong and weak tremors that occur in these regions have a certain influence on the activity of mud volcanoes. In addition, shortly before seismic events some abnormal gas-hydrogeochemical changes are observed in the composition of mud volcanic fluids. In connection with this, in recent years the issue of studying the connection of mud volcanism with seismicity is topical.

Opinions of scientists on the connection of mud volcanism with seismicity were formed in the 19 th century. Ideas were also expressed about the paragenetic connection of seismic events with the activity of mud volcanoes in Azerbaijan $[2 ; 5 ; 6 ; 9$; $12 ; 15 ; 24 ; 43 ; 45-47 ; 51]$, as well as the Sakhalin island [10].

Some monitoring studies were carried out in the mud volcanoes (Demirchi, Madrasa, Gyzmeydan and others) of the Shamakhi-Gobustan seismic active region. The monitoring was related to study the gas and element compositions, as well as temperatures of the fluids on 14 mud volcanoes. The conducted researches covered various periods of activity of mud volcanoes and seismic events. The main tasks of the studies were to investigate the variations in the daily activity of volcanoes, the effect of seismic events on volcanic activity, as well as prediction of earthquakes. Also, carrying out these studies has a significant role on the analysis of both the current database and new results of monitorings for comparative interpretation of similar studies conducted in Russia, and clarification of the reasons for the relationship between mud volcanism and seismic activity. It was carried out the same monitoring in the Yuzhno-Sakhalinsk mud volcano by the Institute of Marine Geology and Geophysics of the Far Eastern Branch of the Russian Academy of Sciences $[14 ; 19 ; 20 ; 23 ; 29]$.

\section{Shamakhi-Gobustan region (Azerbaijan)}

The region occupies a significant part of the southeastern immersion of the Greater Caucasus and is characterized by the widest spread of mud volcanoes with a total number of 120 [25; 48-50]. The sizes of mud volcanoes in the northern part of the region are small (Gyzmeydan, Demirchi, Madrasa, Gushchu and etc.). The largest and most active mud volcanoes are located in the southeastern part of the region, with altitudes up to $400 \mathrm{~m}$.

Mesozoic Cenozoic and Quaternary formations take part in the geological structure of the region [26; $33-35 ; 44]$. Deposits of the Cretaceous and Paleogene are replaced by the Pliocene formations to the south $[3 ; 4]$.

The Central Gobustan zone is composed mainly of Paleogene-Miocene sediments. The thickness of these sediments reach of 2,5-4.5 km [22; 36-42]. Mud volcanoes of this zone are characterized mainly by small size and weak eruptive activity (Fig. 1) [52; 53]. 


\begin{tabular}{l|lr|ll|ll} 
& ISRA (India) & $=\mathbf{1 . 3 4 4}$ & SIS (USA) & $=\mathbf{0 . 9 1 2}$ & ICV (Poland) & $=\mathbf{6 . 6 3 0}$ \\
Impact Factor: & ISI (Dubai, UAE) & $=\mathbf{0 . 8 2 9}$ & PUHL (Russia) & $=\mathbf{0 . 2 0 7}$ & PIF (India) & $=\mathbf{1 . 9 4 0}$ \\
& GIIF (Australia) & $\mathbf{0 . 5 6 4}$ & ESJI (KZ) & $=\mathbf{4 . 1 0 2}$ & IBI (India) & $\mathbf{4 . 2 6 0}$ \\
& JIF & $=\mathbf{1 . 5 0 0}$ & SJIF (Morocco) & $=\mathbf{2 . 0 3 1}$ & & \\
\hline
\end{tabular}

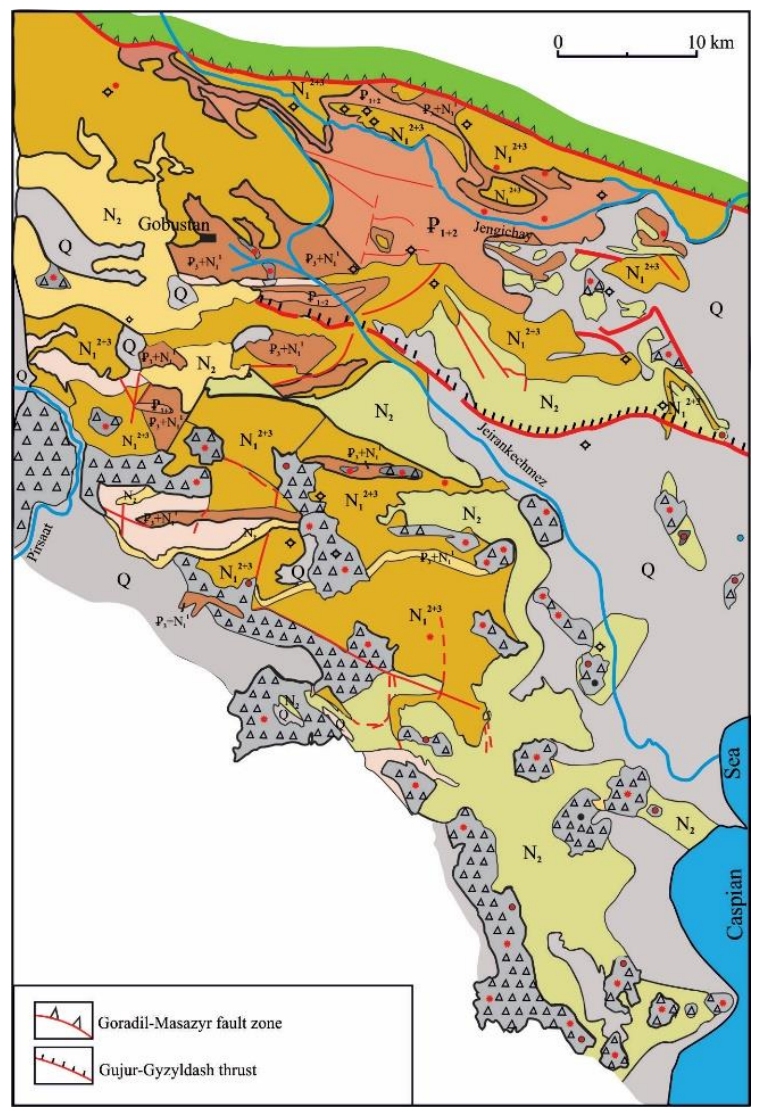

Figure 1 - Geological location map of mud volcanoes in the Central and Southern Gobustan [44].

\section{Sakhalin Island (Russia)}

The Island is part of the Asia-Pacific transition zone from continent to the ocean and is an area of intense seismic tectonic activity [18]. Sakhalin is characterized by a wide distribution of powerful marine Paleogene and Neogene deposits, large concentrations of fossil stone and brown coals associated with continental strata, and widely manifested fields of oil and gas.

Sedimentary and volcanogenic-sedimentary formations of the Mesozoic and Cenozoic were recorded in the geological structure of the island [13].

The island is divided by a system of deep faults intersecting it in the longitudinal direction, through which a gas-fluid transfer takes place. Their intensity is also regulated by seismic activity. Sakhalin is a unique testing object for gas hydrogeochemical research. Here, 4 areas of mud volcanism and volcanoes are confined to a major regional fault of the Central Sakhalin upthrow-shift (Fig. 2). 


\begin{tabular}{|c|c|c|c|c|c|c|}
\hline Impact Factor: & $\begin{array}{l}\text { ISRA (India) } \\
\text { ISI (Dubai, UAE } \\
\text { GIF (Australia) } \\
\text { JIF }\end{array}$ & $\begin{array}{r}=1.344 \\
=0.829 \\
=0.564 \\
=1.500\end{array}$ & $\begin{array}{l}\text { SIS (USA) } \\
\text { PИHЦ (Russia) } \\
\text { ESJI (KZ) } \\
\text { SJIF (Morocco) }\end{array}$ & $\begin{array}{l}=0.912 \\
=0.207 \\
=4.102 \\
=2.031\end{array}$ & $\begin{array}{l}\text { ICV (Poland) } \\
\text { PIF (India) } \\
\text { IBI (India) }\end{array}$ & $\begin{array}{l}=6.630 \\
=1.940 \\
=4.260\end{array}$ \\
\hline
\end{tabular}

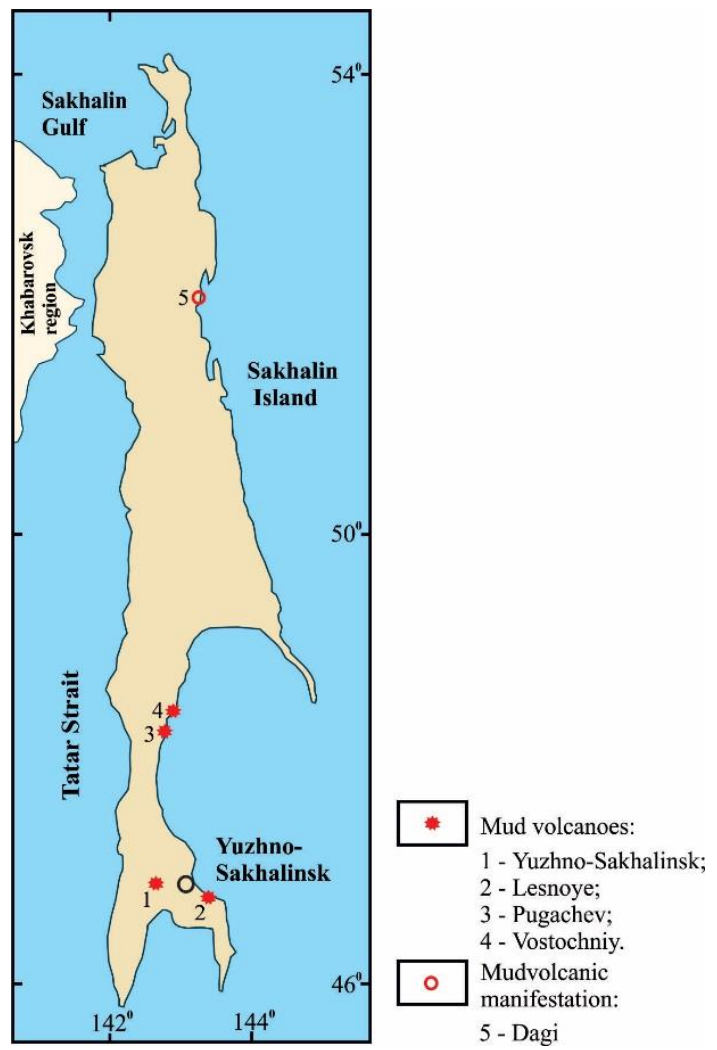

Figure 2 - Location map of mud volcanoes in Sakhalin region [44].

On the island there are two large volcanoes Yuzhno-Sakhalinsk and Pugachevskaya group of mud volcanoes. The first is located $18 \mathrm{~km}$ north-west of the city of Yuzhno-Sakhalinsk, the Pugachev group - $60 \mathrm{~km}$ from the city of Makarov between the village Pugachevo and Vostochniy. On the island there are also three mud volcanoes named Vostochniy, Lesnoye and Dagi. They are related in their activity closer to small mud manifestations [16; 17].

\section{Method and theory}

The regime monitoring observations were conducted daily in the volcanoes of ShamakhiGobustan region. Flow measurement and analysis of chemical compositions of gas and water for each mud volcano were carried out on two or more gryphons. The data were compared with the earthquakes recorded in the region.

On the Sakhalin Island, similar observations were conducted in different gryphons, characterized by varying degrees of activity. The air temperature, the surface of the mud field, the water-mud mixture and the rate of free gases were measured. Measurements were carried out three times a day - in the morning at 9 , in the afternoon at 12 and in the evening at 18 o'clock.

The temperature of the water mud mixture in gryphons were measured with a digital thermometer (Ebro TFX 410).

Gas chromatography was used to analyze the chemical composition of gas samples.

\section{Results and discussion}

In the gas samples of Demirchi mud volcano were established an abnormal values (4.05 and $4.75 \%$ ) for $\mathrm{CO}_{2}$. It was associated with the earthquakes occurred on July 1 and August 3 of the same year. Shortly before the earthquake that occurred in August, for a gas sample of Gyzmeydan mud volcano was recorded the increasing of $\mathrm{He}$ to $0.01 \%$. Anomalous were established in the amount of sulfates $(0.41 \mathrm{mg} / \mathrm{l})$ on the mud volcano Madrasa a few days before the earthquake on August 10. Earthquake preceded increasing boron content in waters mud volcano Ayranteken (137 mg/l), and detection of mercury mud volcano Demirchi (0.013 $\mathrm{mg} / \mathrm{l})$. The anomalous changes in the chemical composition of fluids of mud volcanoes during the earthquake preparation period is shown in table. 


\begin{tabular}{l|lr|ll|ll} 
& ISRA (India) & $=\mathbf{1 . 3 4 4}$ & SIS (USA) & $=\mathbf{0 . 9 1 2}$ & ICV (Poland) & $=\mathbf{6 . 6 3 0}$ \\
Impact Factor: & ISI (Dubai, UAE) $=\mathbf{0 . 8 2 9}$ & PUHЦ (Russia) $=\mathbf{0 . 2 0 7}$ & PIF (India) & $=\mathbf{1 . 9 4 0}$ \\
& GIF (Australia) & $\mathbf{0 . 5 6 4}$ & ESJI (KZ) & $=4.102$ & IBI (India) & $=\mathbf{4 . 2 6 0}$ \\
& JIF & $=\mathbf{1 . 5 0 0}$ & SJIF (Morocco) & $=\mathbf{2 . 0 3 1}$ & & \\
\hline
\end{tabular}

Changing the gas-hydrochemical composition of mud volcanoes connection with seismicity

\begin{tabular}{|c|c|c|c|c|}
\hline Mud volcano & Analysis time & \multicolumn{2}{|c|}{ Components } & Date of earthquake \\
\hline \multirow[t]{4}{*}{ Demirchi } & \multirow[t]{2}{*}{26.06 .1984} & \multirow{2}{*}{$\begin{array}{c}4.05 \% \\
\text { (average } 2 \% \text { ) }\end{array}$} & \multirow[t]{2}{*}{$\mathrm{CO}_{2}$} & 01.07 .1984 \\
\hline & & & & 03.08 .1984 \\
\hline & \multirow[t]{2}{*}{30.07 .1984} & $\begin{array}{c}4.75 \% \\
\text { (averegae } 2 \%)\end{array}$ & $\mathrm{CO}_{2}$ & \multirow[t]{2}{*}{10.08 .1985} \\
\hline & & $0.013 \mathrm{mg} / \mathrm{l}$ & $\mathrm{Hg}$ & \\
\hline Ayrantoken & 06.08 .1985 & $\begin{array}{c}137 \mathrm{mg} / \mathrm{l} \\
\text { (average } 20 \mathrm{mg} / \mathrm{l} \text { ) }\end{array}$ & B & 10.08 .1985 \\
\hline Dashgil & 06.08 .1985 & $\begin{array}{c}110 \mathrm{mg} / \mathrm{l} \\
\text { (average } 38-76 \mathrm{mg} / \mathrm{l})\end{array}$ & B & - \\
\hline Madrasa & 24.08 .1985 & $\begin{array}{c}0.4 \mathrm{mg} / \mathrm{l} \\
\text { (average } 0.24 \mathrm{mg} / \mathrm{l} \text { ) }\end{array}$ & $\mathrm{SO}_{4}$ & 28.08 .1985 \\
\hline \multirow[t]{3}{*}{ Gyzmeydan } & 24.06 .1985 & $0.01 \%$ & \multirow[b]{2}{*}{$\mathrm{He}$} & \multirow[t]{2}{*}{10.08 .1985} \\
\hline & 12.07 .1985 & $0.02 \%$ & & \\
\hline & 27.07 .1985 & $\begin{array}{c}433 \mathrm{mg} / \mathrm{l} \\
\text { (average } 350 \mathrm{mg} / \mathrm{l} \text { ) }\end{array}$ & B & 01.08 .1985 \\
\hline
\end{tabular}

It is assumed that, in contrast to calm mood of mud volcano, during activation, the outlet channel of mud volcano opens somewhat wider, so it results with a flow of gases from deep sources, in which the predominant component is $\mathrm{CO}_{2}$ (Shamakhi-Gobustan region) and $\mathrm{CH}_{4}$ (Sakhalin Island) (Fig. 3).

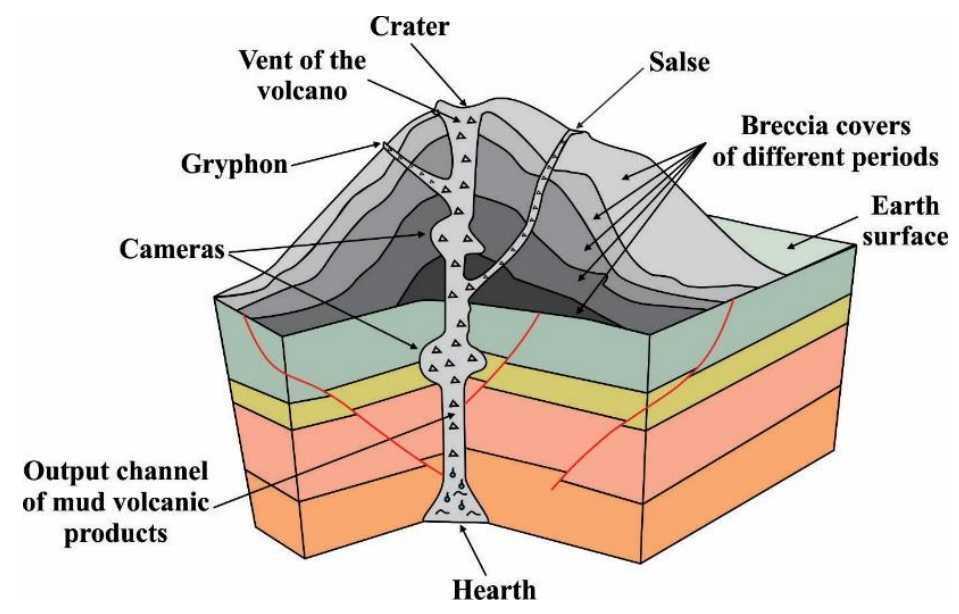

Figure 3 - Conceptual model for mud volcanoes.

The monitoring was conducted on the YuzhnoSakhalinsk mud volcano prior to the Takoiskoe swarm of earthquakes that lasted from late July to mid-September [10]. The strongest earthquake $(\mathrm{M}=$ 5.2) in this period was on September 1 earthquake. Its hypocenter was located in the fault zone of Central Sakhalin, at a depth of 2-14 km. The distance between the hypocenter and volcano is aboute 10-30 $\mathrm{km}$. On July 13-23, in the gryphon of the mud volcano was observed an increase in temperature to $3-4{ }^{\circ} \mathrm{C}$ and in the gas production rate by $2-3$ times, the amount of $\mathrm{Ba}, \mathrm{Ca}, \mathrm{Fe}, \mathrm{Mn}$ carried away from the gryphon of the mud with respect to Al. On August 17 , significant changes were observed on the crater field of the mud volcano, in particular, the formation of a dome with a diameter of 30 and a height of 2 meters. And at the end of December, a powerful eruption of the Yuzhno-Sakhalin mud volcano was recorded.

After Gornozavodsk (August 18, 2006, M = 5.6) and Nevelsk (August 2, 2007, $M=6.1$ ) earthquakes marked a sharp increase in gas production rate by $2-5$ times compared with its average level before the earthquakes (Fig. 4) [29]. 


\begin{tabular}{l|lr|ll|ll} 
& ISRA (India) & $=\mathbf{1 . 3 4 4}$ & SIS (USA) & $=\mathbf{0 . 9 1 2}$ & ICV (Poland) & $=\mathbf{6 . 6 3 0}$ \\
Impact Factor: & ISI (Dubai, UAE) $=\mathbf{0 . 8 2 9}$ & PUHL (Russia) $=\mathbf{0 . 2 0 7}$ & PIF (India) & $=\mathbf{1 . 9 4 0}$ \\
& GIF (Australia) & $\mathbf{0 . 5 6 4}$ & ESJI (KZ) & $=\mathbf{4 . 1 0 2}$ & IBI (India) & $\mathbf{4 . 2 6 0}$ \\
& JIF & $=1.500$ & SJIF (Morocco) & $=\mathbf{2 . 0 3 1}$ & & \\
\hline
\end{tabular}
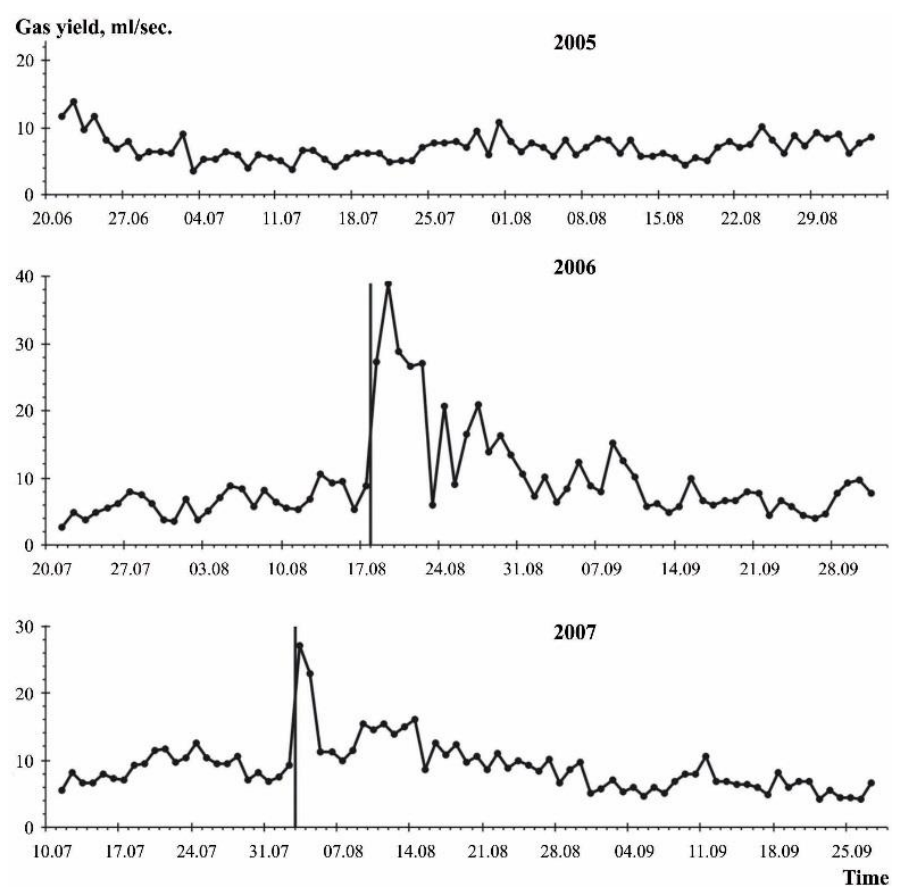

Figure 4 - Change in the rate of free gas flow to the mud volcano Yuzhno-Sakhalinsk during the observation period of 2005, 2006 (Gornozavodsk earthquake) and the 2007 (Nevel earthquake) [29].

After the same earthquake (August 2 and 9) was observed a decrease in $\mathrm{CO}_{2}$ and $\mathrm{CH}_{4}$ increase in all studied gryphons. Concentrations of $\mathrm{CH}_{4}$ were about $28.1 \%$, and $\mathrm{CO}_{2}$ was about $69 \%$ (Fig. 5). It has also been found that immediately after the earthquake (within one hour), the total concentration of hydrocarbon gases significantly increased $[21 ; 27$; 28]. Stabilization of the chemical composition occurred within 70 to 140 days.
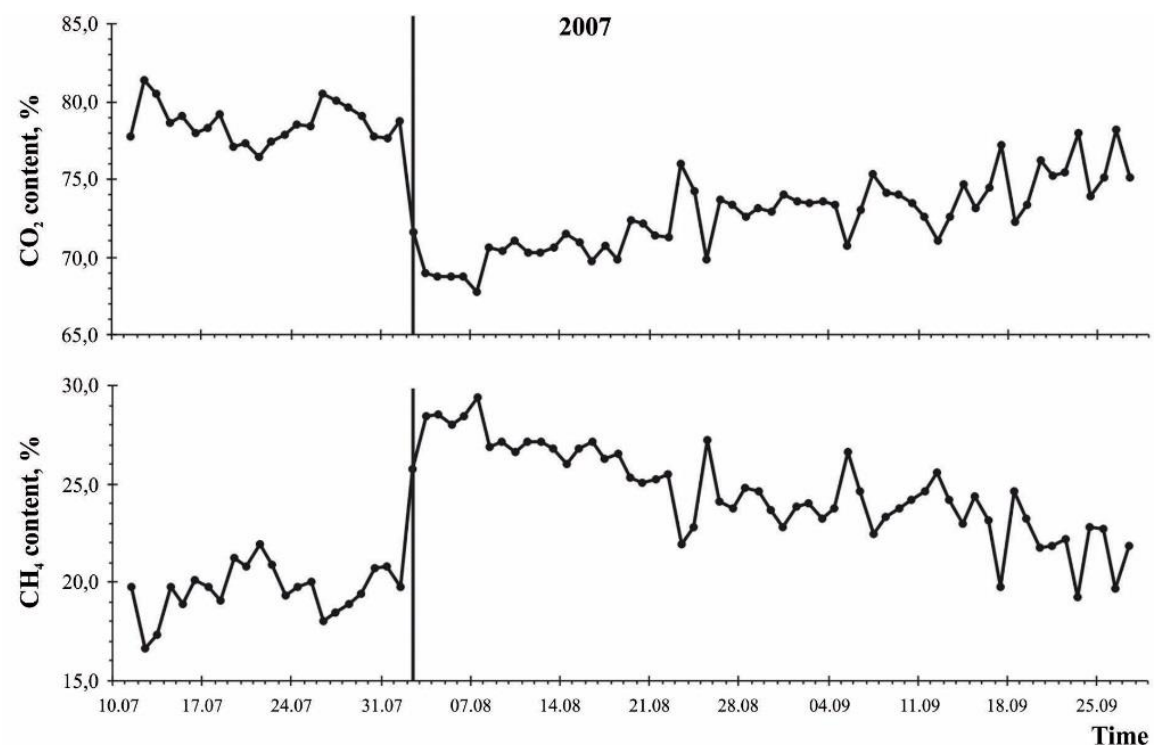

Figure 5 - Chemical composition of free gases in gryphons for the observation period of 2007 with the date of the Nevel earthquake [29].

During the Nevel earthquake, a sharp increase in the $\mathrm{N}_{2}$ content was observed, the minimum contents of which were found in the composition of the gas of all gryphons before the earthquake (Fig. 6) [21]. 


\begin{tabular}{l|lr|ll|ll} 
& ISRA (India) & $=\mathbf{1 . 3 4 4}$ & SIS (USA) & $=\mathbf{0 . 9 1 2}$ & ICV (Poland) & $=\mathbf{6 . 6 3 0}$ \\
Impact Factor: & ISI (Dubai, UAE) $=\mathbf{0 . 8 2 9}$ & PUHL (Russia) $=\mathbf{0 . 2 0 7}$ & PIF (India) & $=\mathbf{1 . 9 4 0}$ \\
& GIF (Australia) & $\mathbf{0 . 5 6 4}$ & ESJI (KZ) & $=\mathbf{4 . 1 0 2}$ & IBI (India) & $\mathbf{4 . 2 6 0}$ \\
& JIF & $=1.500$ & SJIF (Morocco) & $=\mathbf{2 . 0 3 1}$ & & \\
\hline
\end{tabular}

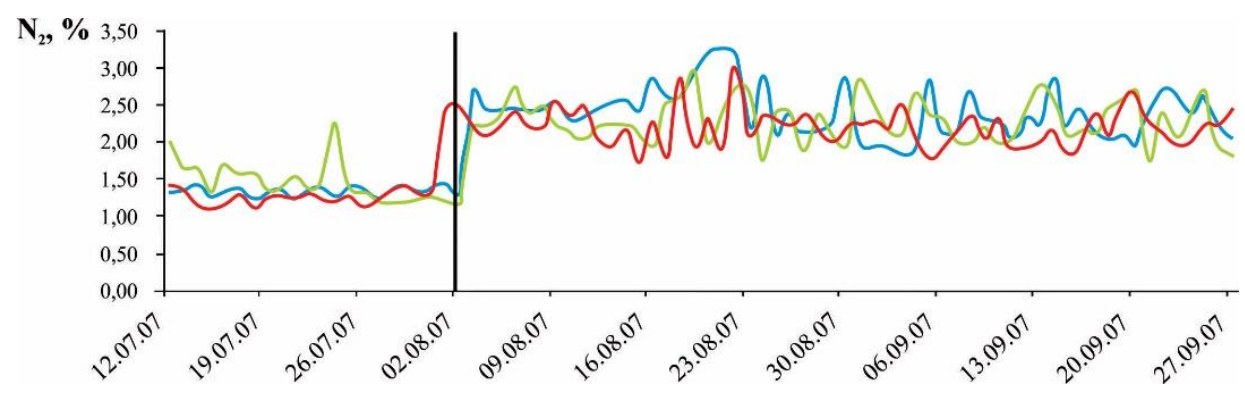

Figure 6 - The nitrogen content of free gases on the mud volcano Yuzhno-Sakhalinsk in the period of observations of 2007 [21].

Blue graph - for gryphon F, green graph - for gryphonG, red graph - for gryphon $\mathrm{H}$, black line - date indicator of Nevelsky earthquake.

In 2006-2007, after the Gornozavodsk and Nevelsk earthquakes, anomalous temperature changes were observed in most active gryphons (Fig. 7) [29].
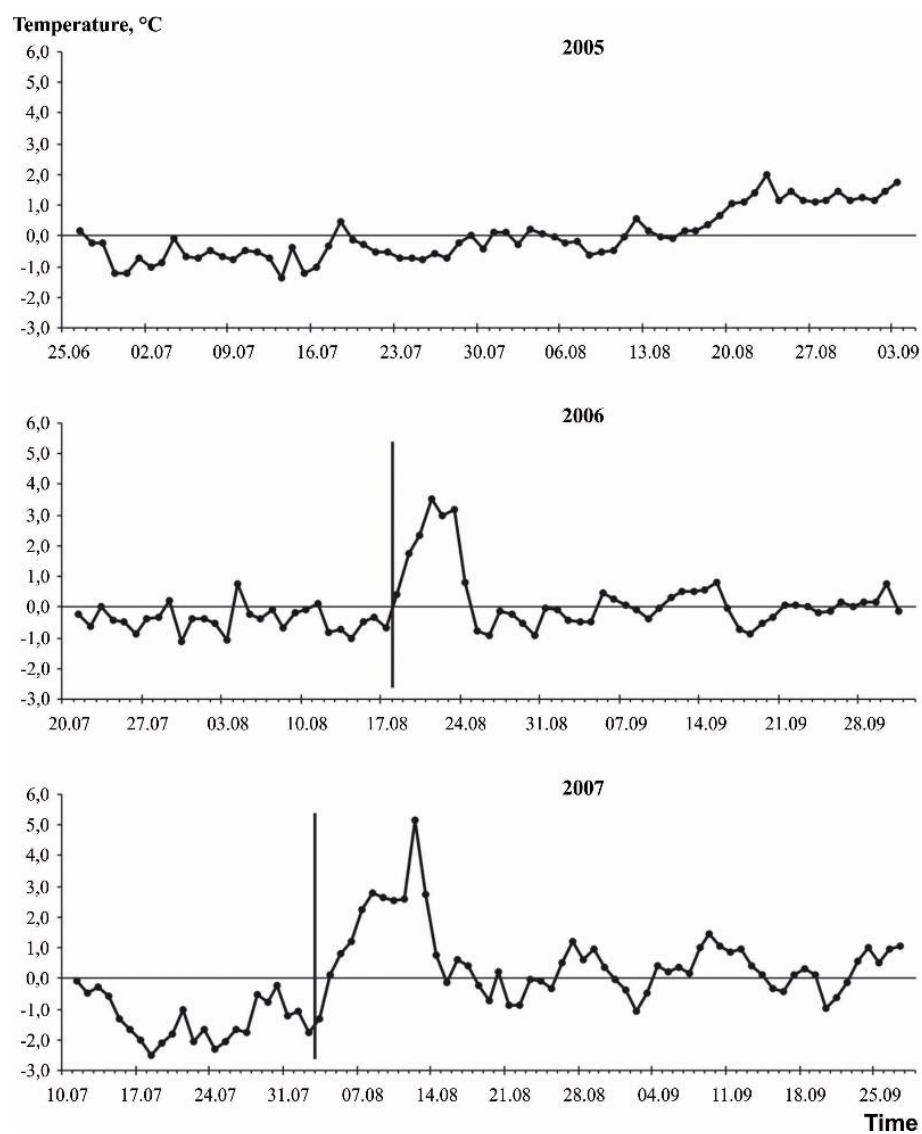

Figure 7 - Temperature changes in gryphons of the mud volcano Yuzhno-Sakhalinsk in 2005, 2006 (the Gornozavodsk earthquake) and 2007 (Nevel earthquake) [29].

\section{Conclusion}

Anomalous changes in the composition of fluids ejected to the Earth's surface by the mud volcanoes of the Shamakhi-Gobustan region and Sakhalin Island in the periods before and after seismotectonic activity were established;

Depending on the strength of the seismic event, anomalous changes occur in the composition of fluids (in gases $\mathrm{CO}_{2}, \mathrm{CH}_{4}, \mathrm{~N}_{2}, \mathrm{He}$, in waters $\mathrm{B}, \mathrm{SO}_{4}$, $\mathrm{Cl})$;

In addition, earthquakes with a large magnitude affect the temperature regime of fluids in gryphons;

During activation, the outlet channel of mud volcano opens wider, so it results with a flow of gases from deep sources, in which the predominant component is $\mathrm{CO}_{2}$ (Shamakhi-Gobustan region) and $\mathrm{CH}_{4}$ ( Sakhalin Island). 


\begin{tabular}{|c|c|c|c|c|c|c|}
\hline Impact Factor: & $\begin{array}{l}\text { ISRA (India) } \\
\text { ISI (Dubai, UAE } \\
\text { GIF (Australia) } \\
\text { JIF }\end{array}$ & $\begin{array}{l}=1.344 \\
=0.829 \\
=0.564 \\
=1.500\end{array}$ & $\begin{array}{l}\text { SIS (USA) } \\
\text { PИНЦ (Russia) } \\
\text { ESJI (KZ) } \\
\text { SJIF (Morocco) }\end{array}$ & $\begin{array}{l}=0.912 \\
=0.207 \\
=4.102 \\
=2.031\end{array}$ & $\begin{array}{l}\text { ICV (Poland) } \\
\text { PIF (India) } \\
\text { IBI (India) }\end{array}$ & $\begin{array}{l}=6.630 \\
=1.940 \\
=4.260\end{array}$ \\
\hline
\end{tabular}

This work was supported by the Science Development Foundation under the President of the Republic of Azerbaijan - Grant № EİF-Mob-8-2017-4(30)-17/06/2.

\section{References:}

1. Abbasov OR, Ibadzade AD, Khasaeva AB, Guseynov AR, Akhundov RV, Baloglanov EE (2014) Uglevodorodnyy potentsial glubokopogruzhennykh otlozheniy Gobustana (Azerbaydzhan) (na osnove goryuchikh slantsev i neftenosnykh porod, vybrosov gryazevykh vulkanov) // Materialy XIV Mezhdunar. nauch. konf. $\quad$ «Resursovospro-izvodyashchie, malootkhodnye i prirodookhrannye tekhnologii osvoeniya nedr», Moskva, 2014, pp. 342-343.

2. Akhmedbeyli FS (1975) Sovremennaya aktivnost gryazevykh vulkanov vostochnoy chasti Azerbaydzhana i ee svyaz s seysmichnostyu // Doklady Akademii Nauk Az. SSR, 1975, t. 31, № 8, pp. 61-64.

3. Akhmedov GA, Zeynalov AM (1975) Geotektonicheskie osobennosti i perspektivy neftegazonosnosti Yuzhnogo Kobystana // Azerbaydzhanskoe neftyanoe khozyaystvo. 1975. № 7. pp. 1-6.

4. Akhmedov GA, Zeynalov MM, Tagiev EA (1976) Shemakhino-Kobystanskaya oblast // Geol. SSSR. Moskva: Nedra, 1976, t. 47, pp. 121-139.

5. Aliev AdA, Gasanov AG, Kabulova AY, Abbasly AA (1989) Gryazevye vulkany i seysmichnost Shemakhino-Gobustanskogo rayona // Materialy yubileynoy sessii, «Posvyashchennoy 50-letiyu IGANA», Baku, 1989, pp. 215-217.

6. Aliev AdA, Gasanov AG, Bayramov AA, Belov IS (2001) Zemletryaseniya i aktivizatsiya gryazevulkanicheskoy deyatelnosti (prichinnaya svyaz i vzaimodeystvie) // Trudy In-ta geol. NAN Azerb. Baku: Nafta-Press, 2001, № 29, pp. 26-38.

7. Aliev AdA, Bayramov AA (2000) Zakonomernost prostranstvenno-vremennogo raspredeleniya gryazevykh vulkanov YuzhnoKaspiyskoy vpadiny v svete novoy tektonicheskoy kontseptsii // Trudy In-ta geol. NAN Azerb. Baku: Nafta-Press, 2000, № 35, pp. 25-45.

8. Aliev AdA (2003) Gryazevoy vulkanizm Yuzhno-Kaspiyskogo neftegazonosnogo basseyna // Trudy In-ta geol. NAN Azerb. Baku: Nafta-Press, 2003, № 3, pp. 21-47.

9. Aliev AdA, Bayramov AA (2008) Vliyanie seysmichnosti na gryazevoy vulkanizm Azerbaydzhana i nekotorye paradoksy // Trudy In-ta geol. NAN Azerb. Baku: Nafta-Press, 2008, № 36, pp. 40-51.

10. Astakhov AS, Sergeev KF, Melnikov OA, Prisyazhnyuk AV, Shakirov RB, Brovko PF, Kiselev VI (2002) Dinamika protsessov deflyuidizatsii Tsentralno-Sakhalinskogo glubinnogo razloma pri seysmicheskoy aktivizatsii (po rezultatam monitoringa YuzhnoSakhalinskogo gryazevogo vulkana $\mathrm{v}$ iyuleavguste 2001 g.) // Doklady RAN, 2002, t. 386, № 2, pp. 223-228.

11. Babaev FR, Abbasov OR, Mamedova AN, Huseynov AR (2013) Izuchenie bitumov Azerbaydzhana // Aktualnye problemy gumanitarnykh i estestvennykh nauk. № 7-1. pp. $40-42$

12. Baloglanov EE, Abbasov OR, Akhundov RV (2016) Gazogidrokhimicheskie pokazateli svyazi gryazevogo vulkanizma s seysmichnostyu // Materialy XXIII Mezhdunar. molod. nauch. konf. studentov, aspirantov i molodykh uchenykh «Lomonosov-2016». Moskva, 11-15 aprelya 2016, pp. 1.

13. (1970) Geologiya SSSR. Ostrov Sakhalin. Geologicheskoe opisanie / Red. V. N. Vereshchagin. Moskva: Nedra, 1970, t. XXXIII, $432 \mathrm{p}$.

14. Levin BV, Kim Chun Un, Tikhonov IN (2007) Gornozavodskoe zemletryasenie 17 (18) avgusta 2006 g. na yuge o-va Sakhalin // Tikhookeanskaya geologiya. 2007. № 2. pp. 102-108.

15. Malinovskiy NV (1938) Seysmy, soprovozhdayushchie gryazevye izverzheniya // Tr. AzFAN SSSR, seriya fizikomatematicheskikh nauk, 1938 , t. $3 / 38$, pp. 6574.

16. Melnikov OA, Ilev AY (1989) O novykh proyavleniyakh gryazevogo vulkanizma na 
Sakhaline // Tikhookeanskaya geologiya. 1989. № 3. pp. 42-49.

17. Melnikov OA, Yershov VV (2010) Gryazevoy (gazovodolitoklastitovyy) vulkanizm ostrova Sakhalin: istoriya, rezultaty i perspektivy issledovaniy // Vestnik DVO RAN, 2010. № 6, pp. 87-93.

18. Kharakhinov VV (2010) Neftegazovaya geologiya Sakhalinskogo regiona. Moskva: Nauchnyy mir, 2010. 275 p.

19. Kim Chun Un, Mikhaylov VI, Sen Rak Se, Semenova YP (2009) Nevelskoe zemletryasenie 02.08.2007: analiz instrumentalnykh dannykh // Tikhookeanskaya geologiya. 2009. № 5. pp. 415.

20. Kim Chun Un, Semenova YP, Zherdeva OA, Sen Rak Se, Mikhaylov VI, Levin YN, Parshina IS, Urban NA, Kasakhara M, Ichiyanagi M, Takakhashi Kh (2011) Katalog zemletryaseniy yuga ostrova Sakhalin za period s 2000 po 2010 g. (po dannym avtonomnykh tsifrovykh seysmicheskikh stantsiy). Vladivostok: Dalnauka, 2011, 357 p.

21. Shakirov RB, Syrbu NS (2012) Prirodnye istochniki metana i uglekislogo gaza na o. Sakhalin i ikh vklad v formirovanie ekologogazogeokhimicheskikh zon // Geoekologiya. 2012. № 4. pp. 344-353.

22. Shikhalibeyli ESh (1995) ShamakhyDzheyrankechmezskiy nalozhennyy progib // Trudy In-ta geol. NAN Azerb. Baku: NaftaPress, 1995, № 25, pp. 218-235.

23. Tikhonov IN (2009) Prognoz silnogo zemletryaseniya na yugo-zapadnom shelfe o. Sakhalin i ego realizatsiya $v$ rezultate Nevelskogo zemletryaseniya 2 avgusta 2007 g. // Tikhookeanskaya geologiya. 2009. № 5. pp. 22-29.

24. Venikova AL, Obzhirov AI, Abbasov OR, Baloglanov EE, Akhundov RV (2014) Gryazevoy vulkanizm i seysmichnost (na osnove sravnitelnogo analiza geokhimicheskikh dannykh gryazevykh vulkanov, raspolozhennykh na o. Sakhalin Rossiyskoy Federatsii i Shamakhy-Gobustanskogo rayona Azerbaydzhana) // Materialy 1-y Mezhdunar. nauch. konf. molodykh uchenykh i spetsialistov «Rol mezhdistsiplinarnogo podkhoda $\mathrm{v}$ reshenii aktualnykh problem fundamentalnykh i prikladnykh nauk (Nauka o Zemlya, tekhnicheskie i khimicheskie)». Baku, 15-16 oktyabrya, 2014, pp. 5-8.

25. Yakubov AA, Dadashev FG, Zeynalov MM, Gadzhiev YA, Magerramova FS, Razvizhina LA (1970) O noveyshikh izverzheniyakh gryazevykh vulkanov yugo-vostochnoy chasti Bolshogo Kavkaza. Baku: Elm, 1970. 117 p.
26. Yakubov AA, Ali-Zade AA, Zeynalov MM (1971) Gryazevye vulkany Azerbaydzhana / Atlas. Baku: Elm, 1971, 256 p.

27. Yershov VV, Shakirov RB, Melnikov OA, Kopanina AV (2010) Variatsii parametrov gryazevulkanicheskoy deyatelnosti i ikh svyaz s seysmichnostyu yuga ostrova Sakhalin // Regionalnaya geologiya i metallogeniya. 2010. № 42. pp. 49-57.

28. Yershov VV, Shakirov RB, Obzhirov AI (2011) Izotopno-geokhimicheskie kharakteristiki svobodnykh gazov Yuzhno-Sakhalinskogo gryazevogo vulkana i ikh svyaz s regionalnoy seysmichnostyu // Doklady Akademii Nauk RAN, 2011, t. 440, № 2, pp. 256-261.

29. Yershov VV (2012) Flyuidodinamicheskie protsessy $\mathrm{v}$ zone Tsentralno-Sakhalinskogo razloma (po rezultatam nablyudeniy na Yuzhno-Sakhalinskom gryazevom vulkane) // Geodinamika i tektonofizika. 2012. t. 3. № 4. pp. 345-360.

30. Yershov VV, Nikitenko OA, Perstneva YA, Baloglanov EE, Abbasov OR (2017) Geokhimicheskie issledovaniya produktov deyatelnosti gryazevykh vulkanov Azerbaydzhana // Sbornik statey V Vserossiyskoy molodezhnoy geologicheskoy konferentsii s mezhdunarodnym uchastiem «Geologiya, geoekologiya i resursnyy potentsial Urala i sopredelnykh territoriy», Ufa, 25-30 sentyabrya 2017, pp. 117-123.

31. Abbasov OR (2010) Possible resources of Gobustan fields and combustible manifestations // Azerbaijan Oil Industry. 2010. issue 5. pp. 59-62.

32. Abbasov OR, Baloglanov EE, Huseynov AR, Akhundov RV (2012) Hydrocarbon potential of Baku Archipelago deep deposits by data of mud volcanoes ejects // Proceeding of the 1st International Conference «Ultra deep hydrocarbon potential: future energy resources - reality and predication». Baku, 2012. pp. 137-139.

33. Abbasov OR, Mamedova AN, Huseynov AR, Baloglanov EE (2013) Some new data of geochemical researches of combustible slates of Azerbaijan // Geology, geophysics and development of oil and gas fields. 2013. vol. 2. pp. 32-35.

34. Abbasov OR, Akhundov RV (2013) The comparative analysis of mud volcanoes of Azerbaijan and Ukraine (an example of Gobustan region and the Kerch Peninsula) // Proceeding of the 5th International Scientific Conference of Young Scientists and Students «Fundamental and applied geological science: achievements, prospects, problems and ways of their solutions». Baku, November 14-16, 2013, pp. 16-18. 
35. Abbasov OR, Akhundov RV (2014) Petroleum potential of Paleogene and Miocene deposits in Gobustan based on oil shale products of mud volcanoes // Baku World Forum of Young Scientists. Baku, 2014. pp. 27-28.

36. Abbasov OR, Baloglanov EE, Akhundov RV (2015) Geochemical analysis of oil shale and oil-bearing rocks of Gobustan mud volcanoes // 6th International Conference of Young Scientists and Students "Multidisciplinary approach to solving problems of geology and geophysics". Baku, October 12-15, 2015, pp. 118-119.

37. Abbasov OR, Baloglanov EE, Akhundov RV (2015) Organic compounds in ejected rocks of mud volcanoes as geological and geochemical indicators: a study from Shamakhi-Gobustan region (Azerbaijan) // International Multidissiplinar Forum "Academic Science Week-2015". Baku, 2015. pp. 3-4.

38. Abbasov OR (2015) Oil Shale of Azerbaijan: Geology, Geochemistry and Probable Reserves // IJRSSET -International Journal of Research Studies in Science, Engineering and Technology. 2015. vol. 2, issue 10. pp. 31-37.

39. Abbasov OR (2016) Distribution regularities of oil shale in Azerbaijan // Theoretical \& Applied Science. 2016. vol. 3. issue 35. pp. 165-171.

40. Abbasov OR (2016) Geological and geochemical properties of oil shale in Azerbaijan and petroleum potential of deepseated Eocene-Miocene deposits // European Journal of Natural History. 2016. vol. 2. pp. 3140.

41. Abbasov OR (2016) Distribution regularities of oil shale in Azerbaijan // ISJ Theoretical \& Applied Science. 2016. vol. 35. issue 3. pp. 165-171.

42. Abbasov OR (2017) Genesis and organic geochemistry of oil shale in Eastern Azerbaijan // Ideas and Innovations in Geosciences, Proceedings of the VII Youth Scientific Conference, Kyiv, Ukraine, 25-27 October, 2017. pp. 33.

43. Aliev AdA, Guliyev IS, Rahmanov RR (2009) Catalogue of recorded of mud volcano eruptions of Azerbaijan (1810-2007). Second edition. Baku: Nafta-Press, 2009. 109 p.

44. Aliev AdA, Guliyev IS, Dadashev FG (2015) Atlas of mud volcanoes in the world. Baku: Publishing house "Nafta-Press", "Sandro Teti Editore", 2015, $321 \mathrm{p}$.

45. Baloglanov EE, Abbasov OR, Akhundov RV, Nuruyev IM (2017) Daily gryphon-salse activity of mud volcanoes and geo-ecological risk (based on researches, conducted in Gaynarja mud volcano) // Water resources, hydraulic facilities and environment. Baku, 2017, pp. 512-517.

46. Baloglanov EE, Abbasov OR, Akhundov RV, Huseynov AR, Abbasov KA, Nuruyev IM (2017) Daily activity of mud volcanoes and geoecological risk: a case from Gaynarja mud volcano, Azerbaijan // European Journal of Natural History. issue 4. pp. 22-27.

47. Baloglanov EE, Abbasov OR, Akhundov RV, Abbasov KA, Nuruyev IM (2017) Impact of seismic activity on fluid (gas and water) and temperature regimes of mud volcanoes in Shamakhi-Gobustan region (Azerbaijan) // Ideas and Innovations in Geosciences, Proceedings of the VII Youth Scientific Conference, Kyiv, Ukraine, 25-27 October, 2017, pp. 31.

48. Bashirov OKh (2016) The mineralogical investigation of the materials of the Keyreki mud volcano // Azerbaijan Geologist. issue 20. pp. 87-90.

49. Bashirov OKh (2017) Some new data of mineralogy of Shikzarli mud volcano // Ideas and Innovations in Geosciences, Proceedings of the VII Youth Scientific Conference, Kyiv, Ukraine, 25-27 October, 2017, pp. 47.

50. Matthieu Dupuis, Francis Odonne, Orxan Abbasov, Teymur Fiqarov, Anthony Dofal, Patrice Imbert, Bruno C. Vendeville (2016) The Ayaz-Akhtarma mud volcano: an actively growing mud pie in the foothills of the Greater Caucasus, Azerbaijan // 13th International Conference on Gas in Marine Sediments. Tromsø, Norway, 2016.

51. Mellors R, Kilb D, Aliyev A, Gasanov A, Yetirmishli G (2007) Correlations between earthquakes and large mud volcano eruptions // Journal of Geophysical Research. 2007. vol. 112. B04304. doi:10.1029/2006JB004489. pp. $1-11$.

52. Orhan Rafael Abbasov (2015) Oil shale of Azerbaijan: geology, geochemistry and probable reserves // International Journal of Research Studies in Science, Engineering and Technology. 2015. vol. 2. issue 9. pp. 31-37.

53. Orhan R* and Abbasov (2016) Organic compounds in ejected rocks of mud volcanoes as geological and geochemical indicators of source rock: a study of oil shale in ShamakhiGobustan region (Azerbaijan) // International Journal of Current Advanced Research. 2016. vol. 5. issue 7. pp. 1042-1046. 